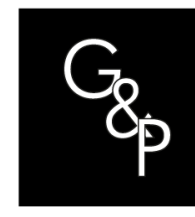

\title{
Effects of coexistence of marketing and operations on product innovation performance
}

\section{Coexistência de marketing e operações e o sucesso da inovação}

\author{
Jandir Balensiefer Vicenzi ${ }^{1}$ (D), Verner Luis Antoni ${ }^{1}$ (D), Claudio Damacena ${ }^{2}$ (D), \\ Carlos Henrique Riss ${ }^{1}$ (D), Thayane Woellner Sviercoski Manosso ${ }^{1}$ (D) \\ ${ }^{1}$ Universidade de Passo Fundo - UPF, Programa de Pós-graduação em Administração, Passo Fundo, RS, Brasil. \\ E-mail: jandirvicenzi@gmail.com; antoni@upf.br; carlosriss@hotmail.com; thay_thay3@hotmail.com \\ ${ }^{2}$ Pontifícia Universidade Católica do Rio Grande do Sul - PUCRS, Programa de Pós-graduação em Administração, \\ Porto Alegre, RS, Brasil. E-mail: claudio.damacena@pucrs.br
}

How to cite: Vicenzi, J. B., Antoni, V. L., Damacena, C., Riss, C. H., \& Manosso, T. W. S. (2020) Effects of coexistence of marketing and operations on product innovation performance. Gestão \& Produção, 27(1), e4039. https:// 10.1590/0104-530X4039-20

\begin{abstract}
The present study aimed at investigating the impact of the coexistence of marketing and operations on product innovation performance in the flexible plastic packaging industry in Brazil. To this end, the study was conducted in two stages: one, exploratory and qualitative, and the other, descriptive and quantitative. In the first stage, a construct was chosen and validated to identify the effect of integrating the functions of innovation and develop an instrument for data collection. In the second stage, we defined the research population, collected data, and performed statistical analysis of the results. To measure the relationship of marketing and operations, we used a theoretical construct which investigates the level of integration in the four phases of the new product development process and innovation performance, considering both financial and non-financial dimensions. Data were collected through a structured questionnaire and statistically analyzed through linear regression and correlations between variables. The results showed that the integration of these areas has a positive and significant impact on the success of innovation, indicating that information-sharing in the initial and final stages of the product innovation process is a driver for achieving better performance. One of the main findings of this study is that, in isolation, the field of marketing does not perceive the impact of the integration of functions on innovation.
\end{abstract}

Keywords: Integration; Marketing; Operations; Innovation performance.

Resumo: $O$ presente estudo teve como objetivo investigar o impacto da coexistência de marketing e operações no desempenho em inovação de produtos, na indústria de embalagens plásticas flexíveis do Brasil. Para alcançar o objetivo proposto, o estudo ocorreu em duas etapas, uma exploratória e qualitativa e outra descritiva e quantitativa. Na primeira, foi definido e validado o construto para identificar o efeito da integração entre as funções na inovação e elaborado o instrumento de coleta de dados. Na segunda, procedeu-se a definição da população da pesquisa, a coleta de dados e a análise estatística dos resultados. Para mensurar a relação de coexistência entre marketing e operações, utilizou-se um construto teórico que investiga o nível de integração nas quatro fases do processo de desenvolvimento de novos produtos e o desempenho em inovação, considerando dimensões financeiras e não financeiras. Os dados foram coletados por meio de um questionário estruturado e analisados

Received May 29, 2017 - Accepted Dec. 13, 2017 Financial support: None.

This is an Open Access article distributed under the terms of the Creative Commons Attribution License, which permits unrestricted use, distribution, and reproduction in any medium, provided the original work is properly cited. 
estatisticamente por meio de regressão linear e correlações entre as variáveis. Os resultados evidenciaram que a integração entre as áreas tem impacto positivo e significativo no sucesso da inovação, indicando que os direcionadores para o alcance de um melhor desempenho encontram-se no compartilhamento de informações nos estágios iniciais e finais do processo de inovação em produtos. A verificação das percepções das duas áreas, isoladamente, indicou que a área de marketing não percebe a relação da integração entre as funções e a inovação, tornando-se essa uma das principais contribuições do estudo.

Palavras-chave: Integração; Marketing; Operações; Desempenho em inovação.

\section{Introduction}

The marketing and operations functions are key areas in organizations as they are responsible for delivering added value to customers (Piercy, 2007). These two areas are responsible for the basic duties of any organization, specifying what is produced, how it is produced, and how products and services are delivered (Tang, 2010) while promoting the interaction between the organization and the customer (Hill, 2005). In this context, a better integration of marketing and operations, in a collaborative and cooperative environment, is of fundamental importance to create and sustain competitive advantages (Piercy, 2007; Kong et al., 2015).

The need for greater integration of the marketing and operation areas is justified by their important roles of understanding the needs and desires of customers and delivering products and services aligned with these expectations. Piercy (2007) emphasizes that to satisfy such expectations with excellence, a close congruence between what is promised by marketing and what is delivered by operations is needed.

As evidenced by Swink \& Song (2007) and Song et al. (2010), marketing and operations are the functional areas that play bigger roles in the development of new products. However, although the functions are responsible for key activities in innovation, different objectives and perspectives inherent to each function often lead to conflicts and misunderstandings in the development of new products (Xie et al., 2003). The dominance of one or another perspective may lead to deficiencies in innovation, both regarding market relevance and the company's ability to deliver what has been promised with excellence (Swink \& Song, 2007).

In this sense, marketing strategies and operations need to be closely integrated to achieve success in product innovation (Swink \& Song, 2007; Song et al., 2010). As evidenced by the literature, further studies on the integration of marketing and operations in organizations is needed. Moreover, this subject is considered important for further research by both national (Paiva et al., 2011; Zanon, 2011; D'Avila, 2013) and international (Kahn \& Mentzer, 1994, 1998; Hausman et al., 2002; Malhotra \& Sharma, 2002; Piercy, 2007; Kwortnik \& Thompson, 2009; Tang, 2010; Song et al., 2010; Kong et al., 2015) authors. In this context, further studies on the integration of these areas, using theories from a cross-cultural perspective, especially considering developing countries (Keskin, 2006; Song et al., 2010; Kong et al., 2015), are of great value to the academy.

Given that companies in the flexible plastic packaging industry face a complex and dynamic environment, they need to offer fast and innovative solutions for their customers that add value to the final consumers at low costs. According to Camilo (2016), the speed of information and the current changes imposed on the companies in this industry require them to possess innovation capability and have a product 
development process faster than their competitors. According to the author, innovation for the companies in this industry is a matter of survival (Camilo, 2016). This competitive context reinforces the importance of integrating marketing and operations in increasing innovation capability and consequently, contributing to the development of competitive advantage.

Taking an economic perspective, according to the Brazilian Packaging Association (ABRE, 2016), the Brazilian packaging industry's growth in 2016 was $6.6 \%$ compared to 2015 , reaching $R \$ 64.3$ billion, which represents $1.03 \%$ of the gross domestic product. The Brazilian Association of Flexible Plastic Packaging Industry (ABIEF, 2017), in turn, reported that the domestic market for this type of packaging grew by $1.6 \%$ in the first half of 2017 when compared to the same period in 2016; this is in accordance with the economic reality of Brazil which is experiencing a recession, with a drop in economic activity of $-4.08 \%$ in 2015 and $-3.40 \%$ in 2016 (IBGE, 2017).

Thus, this study aimed at investigating the coexistence of marketing and operations in the flexible plastic packaging industry in Brazil, assessing the impact of the integration of these functions on product innovation performance. In doing so, we used the construct of Song et al. (2010) which was already tested and validated with American and Japanese managers. We considered the relationship between marketing and operations from a functional and non-departmental perspective, which, according to D'Avila (2013), is not widely explored in studies on the integration of the two areas as functions that act together and share common goals (Piercy, 2007; Kong et al., 2015).

Besides the introduction, this article is organized in six other sections: the second section presents the theoretical framework, the third is about the hypothesis tested, the fourth explains the methods employed, the fifth discusses the analysis of results, and finally, the sixth section presents the conclusions.

\section{Theoretical framework}

Considering the important roles of marketing and operations in organizations, the relationships between these areas have been studied by researchers since the late 1960s. Seminal articles published by Skinner (1969) and Shapiro (1977) were precursors in drawing the attention of the academe and managers to the relevance of this subject by indicating incongruities of the two functions.

Skinner (1969), in addressing the development of corporate strategy, indicates as a challenging question the challenge of aligning marketing and operations strategies by asking,

If we are competing with product $X$, with price $Y$ to serve customers $Z$, using certain distribution channels and forms of communication, what will be required of manufacturing regarding costs and deliveries, lead time, quality levels and reliability?" (Skinner, 1969, p. 144).

Following this logic, Shapiro (1977) took up the discussion questioning whether marketing and manufacturing could coexist. According to the author, on the one hand, the marketing team often blames the production team for lack of market orientation and, on the other hand, the production area members blame the marketing area members for lack of understanding of costs, profits, production, and operations (Shapiro, 1977). 
Malhotra \& Sharma (2002), in the special issue of the Journal of Operations Management, in turn, taking up the classic Shapiro (1977) on the interface between the functions, inquire whether marketing and production could not coexist in the current context. The authors emphasize that in the face of technological advances and globalization, the relationship between the functions is a challenge which is forcing companies to simultaneously seek efficiency and speed in responding to the new demands of the market.

Tang (2010) argues that marketing and operations need to coexist, stating that coordination between what to do as defined by the marketing plan, and how to do it, defined by the operations, is essential for a company to compete successfully. The author indicates the "[...] need for further research on coexistence, examining ways to improve coordination between the marketing and operations functional areas" (Tang, 2010, p. 23).

D'Avila (2013), studying the relationship between marketing and operations, emphasizes that this subject can be approached from two perspectives: first, using the structural approach, by evaluating the relationship of the areas and considering each area as a department that operates separately, and the second, based on functional relations, by evaluating the functions performed by marketing and operations on the basis of activities and not by organizational structures. Day (1997) indicates that companies tend to evolve into more hybrid organizational formats, using horizontal processes and verticalized functions to get close to customers, thus better serving their needs. In this context, it is necessary to create new knowledge within the company (Calantone \& Rubera, 2012) and to share this information through functional limits, in order to respond more quickly to changes in the market (Jaworski \& Kohli, 1993; Frishammar et al., 2012).

As shown in Chart 1, Kong et al. (2015) approach the relationship between marketing and operations as functions rather than departments, considering that information-sharing is the determinant for the success of the product innovation process.

Chart 1. Definitions of integration between marketing and operations.

\begin{tabular}{|c|c|}
\hline Author & Definition of integration between marketing and operations \\
\hline Kahn \& Mentzer (1998) & $\begin{array}{l}\text { Collaborative process with work teams and shared } \\
\text { resources aiming to achieve collective goals. }\end{array}$ \\
\hline O’Leary-Kelly \& Flores (2002) & $\begin{array}{l}\text { The extent to which the functions work together and } \\
\text { cooperatively to arrive at mutually acceptable results, } \\
\text { encompassing constructions related to the degree of } \\
\text { cooperation, coordination, interaction, and collaboration. }\end{array}$ \\
\hline Tang (2010) & $\begin{array}{c}\text { Coordination and collaboration of strategic and operational } \\
\text { activities between the areas. }\end{array}$ \\
\hline Mollenkopf et al. (2011) & $\begin{array}{c}\text { The way the functions communicate with each other, } \\
\text { coordinate their activities, and align them to the } \\
\text { achievement of common goals. }\end{array}$ \\
\hline Kong et al. (2015) & $\begin{array}{c}\text { The degree of information-sharing, coordination, and } \\
\text { involvement of the functions in the development of new } \\
\text { products. }\end{array}$ \\
\hline
\end{tabular}

Source: Authors.

The literature indicates the integration of the key areas of marketing decision-making and operations as an important source of competitive advantage, which creates 
superior value for customers (Shapiro, 1977; Narver \& Slater, 1990; Piercy, 2007; Kong et al., 2015). Regarding performance, although it is believed that the integration of the two functions may lead to superior performance, the empirical research supporting this relationship is still scarce (Malhotra \& Sharma, 2002; Paiva et al., 2011). Thus, several authors suggest further research investigating the impact of the integration of these functions on organizational performance in other sectors and environments (O'Leary-Kelly \& Flores, 2002; Song et al., 2010; Kong et al., 2015). In Brazil, some studies found that integration of marketing and operations is positively associated with performance (Zanon, 2011; D'Avila, 2013), while others have found no evidence for this relation (Paiva et al., 2011).

When researching the relationship between marketing and operations, it is observed that the production of goods and services are different, mainly in the operational methods of three areas: production planning and control, product and process design, and quality control (Orsini \& Karagozoglu, 1988; Basnet, 2013). The traditional separation between production and marketing in manufacturing companies, with products serving the interaction between these functions, is not appropriate for services (Fitzsimmons \& Fitzsimmons, 2014; Motta \& Moraes, 2017). In service providers, some of the marketing functions, such as making the consumer an active participant and smoothing the demand so that it does not exceed the production capacity, must have a coordination between the production process and workforce, integrating the operations and marketing functions (Fitzsimmons \& Fitzsimmons, 2014).

The estimation and performance of services occur simultaneously, i.e., company and consumers interact in order to the company understand the demand and, when necessary, make supply adjustments (D'Avila, 2013). Thus, considering the intangibility (Tomaszewski et al., 2016), perishable capacity, difficult measurement, and customer involvement, innovations in services should be perceived as a continuous process (Fernandes et al., 2017). Therefore, in services, the interaction between marketing and operations is more complex, since the customer is involved when the service is performed (Orsini \& Karagozoglu, 1988). In goods production, cooperation between marketing and operations usually increases as the production process moves from an early to a later stage, and is a key determinant of innovative products' performance in the late stages (Olson et al., 2001), that is, the importance of cooperation between the functions varies according to the stage of production and the level of innovation (Olson et al., 2001; Homburg et al., 2017).

Product innovation is defined as the process of designing, creating, and launching new products for a company, a market, or the world (Sivakumar \& Nakata, 2003), while innovation performance refers to the degree of success achieved by the company with new products on the market (Henard \& Szymanski, 2001). Observing the high rates of failure in the development of new products, Kong et al. (2015) e Ma et al. (2015) highlight the importance of performing further research aimed at investigating the impact of the coexistence between the marketing and operations functions on innovation success.

Ma et al. (2015) state that product innovation is an important tool to address competition in the global marketplace, ensuring survival and shaping the future of companies in the long run. The success in product innovation reflects the company's ability to compete in the market (Baker \& Sinkula, 1999). Thus, organizations must take an innovative approach, introducing new products and services quickly and 
effectively, aiming at achieving sustainable competitive advantages (Fallah \& Lechler, 2008).

New product development projects usually evolve through four fundamental stages: analysis of market opportunities; technical development of the product and testing; preparation of marketing plans; and launch of the new product on the market (Crawford \& Di Benedetto, 2008). The first stage consists of a complete and thorough analysis of the market, aimed at developing a competitive product that delivers added value to customers (Kong et al., 2015). Technical development of the product and testing include studies on product and process engineering, the establishment of specifications, prototype development, and final product approval (Swink \& Song, 2007). The preparation of marketing plans stage consists of the establishment of general objectives and the development of the marketing strategy, which based on the analysis of the current situation and market opportunities, outlines specific tactics regarding advertising, forms of commercialization, pricing, channels, and services. Finally, in the launch of the product stage, efforts are focused on all activities required to launch the product on the market, including manufacturing and marketing planning, promotion, and distribution (Swink \& Song, 2007; Kong et al., 2015).

Regarding the different challenges and uncertainties inherent to each of new product development stages, Song et al. (2010) and Lin et al. (2015) emphasize that exchanging and sharing information between functions is a key factor in the success of the project. Simultaneous integration of information among all phases of the new product development process provides capabilities that facilitate the exchange, reconfiguration, and use of resources, contributing to superior performance by leveraging the synergy of cooperation between the functions (Kong et al., 2015).

The positive impact of the integration of marketing and operations functions in innovation success was found in several studies, from which we highlight the cross-cultural study of Song et al. (2010), done on American and Japanese managers and the studies of Swink \& Song (2007) and Kong et al. (2015) conducted in the United States and China, respectively, which evaluated the impact of integration of the functions at each stage of the new product development process.

\section{Hypotheses of the study}

To formulate the first hypothesis we considered theoretical and empirical studies that found a positive relationship between the integration of marketing and operations functions and organizational performance (O'Leary-Kelly \& Flores, 2002; Song et al., 2010; D'Avila, 2013); marketing functions and operations as precursors of key activities in development of new products (Tatikonda \& Montoya-Weiss, 2001; Swink \& Song, 2007; Song et al., 2010); and studies supporting that the integration of these functions increases the innovation performance in new product development (Calantone et al., 2002; O'Leary-Kelly \& Flores, 2002; Song et al., 2010; Kong et al., 2015). Thus, we hypothesize:

Hypothesis 1 - There is a positive relationship between marketing and operations integration and product innovation success.

Considering the importance of exchanging and sharing information between marketing and operations in the different stages of the new product development process (Swink \& Song, 2007; Song et al., 2010; Schneider \& Engelen, 2015; Lin et al., 2015) and integration of knowledge of both functions to promote superior innovation performance in the development of new products (Song et al., 2010; 
Frishammar et al., 2012; Peng et al., 2013; Lin et al., 2015; Kong et al., 2015), we propose hypotheses 2, 3, 4 and 5:

Hypothesis 2 - Information sharing between marketing and operations in the analysis of market opportunities has a positive effect on innovation.

Hypothesis 3 - Information-sharing between marketing and operations in marketing and sales-testing before the launch of the product has a positive effect on innovation.

Hypothesis 4 - Information-sharing between marketing and operations in the preparation of marketing plans has a positive effect on innovation.

Hypothesis 5 - Information-sharing between marketing and operations in the launch of new products on the market has a positive effect on innovation.

\section{Method}

A literature review was conducted in the publications portal of the Coordination for the Improvement of Higher Education Personnel (CAPES) and the EBSCO and PROQUEST databases using Portuguese and English keywords. First, we searched for the keywords "marketing" and "operations" and then other related terminologies such as "manufacture" and "production;" subsequently, by other keywords about the relationship between the two functions: "collaboration," "coordination," "integration," "interface," and "inter-functional." The literature review was conducted between 2015 and 2017.

In the exploratory and qualitative first stage, a construct was chosen and validated in order to measure the relationship between the integration of marketing and operations, and organizational in developing the data collection instrument. In the second stage, which was descriptive and quantitative, population and subjects were chosen, data were collected, and the results statically analyzed.

Considering that few studies and constructs investigated the benefits of a greater integration between the functions and innovation success (Swink \& Song, 2007; Song et al., 2010; Kong et al., 2015), and the existing ones focus mainly on an analysis in the business level and the technical stages of products development (Olson et al., 2001; Swink \& Song, 2007; Song et al., 2008), we chose the theoretical construct of Song et al. (2010) for this study. The following criteria were considered when making this choice: (i) the model was tested and assessed for discriminant validity, dimensionality, convergent validity, and reliability, with robustness and general applicability for further research; (ii) the model was used in the same industrial sector of this research; (iii) the construct was used in a cross-cultural study and in several industrial segments which demonstrates its applicability in different cultures and organizations; (iv) the author uses innovation as a measure of performance; and (v) the proposed concept approaches the subject from a functional and non-departmental perspective on the integration of marketing and operations.

The construct was validated by translation from English, the original language of Song et al. (2010) study, to Portuguese, using the reverse-translation method. Subsequently, the construct was validated by judges, from academia and practice, as indicated by Malhotra (2004). Among the scholars, there were three researchers from masters' and doctoral programs in the business administration area, with specific knowledge on the subject and marketing metrics. The construct was then validated by 
a marketing director of a company that manufactures flexible plastic packaging in order to adjust the language to the terminology inherent to the industry studied.

The questionnaire, based on the model by Song et al. (2010), was structured in two blocks. The first addresses the integration between the functions through analysis of information-sharing between the areas in the different stages of the development of new products. The second block evaluates innovation performance through the analysis of financial and non-financial indicators, verifying profitability, sales success, product development cycle time, and portfolio range. A five-point Likert-type scale was used for both blocks. The approach adopted for analysis of the performance of the companies was subjective, evaluating organizational performance according to the perception of the managers in relation to competition. Eight professionals from the flexible plastic packaging industry conducted the test using the data-collection instrument; four were marketing managers, and four were operations managers.

The total population consisted of 319 flexible plastic packaging companies in Brazil, with 143 companies present in the ABIEF databases and 176 companies belonging to eleven regional unions representing the segment in several Brazilian states. We chose this industry because of the economic and social importance of the segment for the Brazilian economy and the sector's strong focus on technology and innovation, as pointed out by Camilo (2016). The respondents of the research were managers and directors from the areas of marketing and commercial, and production and operations.

Data were collected from June 27 to July 15, 2016. After identifying the managers responsible for the marketing and operations areas, 207 questionnaires were first sent through e-mail. A total of 32 valid questionnaires returned, corresponding to a rate of return of $15.4 \%$, a percentage considered satisfactory according to Malhotra (2004). In the second stage of data collection, conducted through telephone calls, another 50 managers responded, totaling 82 valid questionnaires; 41 of which were answered by marketing and commercial managers and 41 by managers in the production and operations. $T$-test evaluation indicated that both groups did not have significant statistical differences. A convenience sample was used and the managers of each area did not necessarily work in the same company.

For data analysis, descriptive analysis of the sample, analysis of reliability level of the constructs using Cronbach's alpha, and multivariate data analysis were performed. For hypothesis testing, variance analysis (Hair et al., 2005) and correlation analysis (Malhotra, 2004) between the independent variable, integration of marketing and operations, and the dependent variable, innovation performance, were performed using the Statistical Package for Social Sciences (SPSS) statistical software.

\section{Results}

In order to categorize the companies by size, we used the classification proposed by the Micro and Small Business Support Service (SEBRAE, 2013). The sample consisted mainly of medium-sized organizations; 51 companies corresponding to $62.2 \%$ of the total sample. The others were small companies, with 20 to 99 employees ( 26 or $31.7 \%$ of the total), and large companies ( 5 or $6.1 \%$ of the 
total). Regarding the profile of the respondents, as shown in Table 1, the sample is composed of more managers than directors.

Table 1. Position of respondents.

\begin{tabular}{ccccc}
\hline Respondent area & Position held & $\begin{array}{c}\text { Absolute } \\
\text { frequency }\end{array}$ & $\begin{array}{c}\text { Relative } \\
\text { frequency \% }\end{array}$ & $\begin{array}{c}\text { Cumulative } \\
\text { frequency \% }\end{array}$ \\
& Operations manager & 1 & 2.4 & 2.4 \\
& Production manager & 5 & 12.2 & 14.6 \\
\cline { 2 - 5 } $\begin{array}{c}\text { Production and } \\
\text { operations }\end{array}$ & Industrial manager & 26 & 63.4 & 78.0 \\
\cline { 2 - 5 } & Industrial director & 7 & 17.1 & 95.1 \\
\cline { 2 - 5 } & Technical director & 2 & 4.9 & 100.0 \\
\cline { 2 - 5 } & Total & $\mathbf{4 1}$ & $\mathbf{1 0 0}$ & 100 \\
\hline \multirow{2}{*}{$\begin{array}{c}\text { Marketing and } \\
\text { commercial }\end{array}$} & Marketing manager & 1 & 75.6 & 75.6 \\
\cline { 2 - 5 } & Sales manager & 2 & 2.4 & 78.0 \\
\cline { 2 - 5 } & Commercial director & 7 & 4.9 & 82.9 \\
\cline { 2 - 5 } & Total & $\mathbf{4 1}$ & 17.1 & 100.0 \\
\hline & Total & $\mathbf{8 2}$ & $\mathbf{1 0 0}$ & 100 \\
\hline
\end{tabular}

Source: Authors.

In the production and operations areas, there were more respondents who were managers and directors of industrial and production areas than those of technical and operations areas. Among the respondents in the marketing and commercial areas, we can observe more representatives of the sales area and only a single manager from the strategic marketing area. This finding indicates that most companies do not formally establish a marketing team, transferring these responsibilities to the sales force or an advertising agency (Campomar \& Ikeda, 2006; Kotler et al., 2006). This perspective based on short-term operational activities and results is in contrast with the essence of strategic marketing in disseminating a culture of market orientation throughout the organization, seeking for long-term performance (Jaworski \& Kohli, 1993).

The reliability of the internal measurements of each construct was assessed separately. Integration of marketing and operations, the first construct, had a Cronbach's alpha of 0.78 , which indicates good reliability according to the classification proposed by Hair et al. (2005). After scaling (Hair et al., 2005), we identified the need to eliminate the last variable of innovation performance construct: [...] our product portfolio is more diverse than that of our competitors. Then, Cronbach's alpha of innovation performance became 0.66 , which indicates a moderate and acceptable association (Hair et al., 2005).

Table 2 shows that the means of all variables that compose the construct are above the midpoint of the scale, with a total mean of 3.80 . Analyzing the means obtained for the four variables, it can be observed that the managers of both areas had the same opinion on the sequence of stages in which more information is shared between the areas. However, the professionals of the production and operations areas perceived a lower level of information than the professionals of the marketing and commercial areas. The stage in which more information is shared is the last one, the launch of new products, with a mean of 4.07 and following, with a mean of 3.98 is testing of products. 
Table 2. Integration of marketing and operations.

\begin{tabular}{|c|c|c|c|c|}
\hline \multirow[b]{2}{*}{$\begin{array}{l}\text { Variables - Integration of } \\
\text { marketing and operations }\end{array}$} & & \multicolumn{3}{|c|}{ Respondent functional area } \\
\hline & & $\begin{array}{l}\text { Marketing } \\
\text { and Sales } \\
n=41\end{array}$ & $\begin{array}{l}\text { Production } \\
\text { and } \\
\text { Operations } \\
n=41\end{array}$ & $\begin{array}{l}\text { Total } \\
\mathrm{n}=82\end{array}$ \\
\hline \multirow{3}{*}{$\begin{array}{l}\text { Information are shared } \\
\text { between marketing and } \\
\text { production for the analysis } \\
\text { of market opportunities. }\end{array}$} & Mean & 4.10 & 3.66 & 3.88 \\
\hline & Median & 4.0 & 4.0 & 4.0 \\
\hline & Standard deviation & 1.068 & 0.990 & 1.047 \\
\hline \multirow{3}{*}{$\begin{array}{l}\text { Information are shared } \\
\text { between marketing and } \\
\text { production for marketing } \\
\text { and sales testing before the } \\
\text { product is launched. }\end{array}$} & Mean & 4.12 & 3.83 & 3.98 \\
\hline & Median & 4.0 & 4.0 & 4.0 \\
\hline & Standard deviation & 1.122 & 0.892 & 1.018 \\
\hline \multirow{3}{*}{$\begin{array}{l}\text { Information are shared } \\
\text { between marketing and } \\
\text { production for preparing } \\
\text { marketing plans. }\end{array}$} & Mean & 3.46 & 3.12 & 3.29 \\
\hline & Median & 3.0 & 3.0 & 3.0 \\
\hline & Standard deviation & 1.164 & 1.144 & 1.160 \\
\hline \multirow{3}{*}{$\begin{array}{l}\text { Information are shared } \\
\text { between marketing and } \\
\text { production for launch of new } \\
\text { products on the market. }\end{array}$} & Mean & 4.24 & 3.90 & 4.07 \\
\hline & Median & 5.0 & 4.0 & 4.0 \\
\hline & Standard deviation & 1.067 & 0.995 & 1.040 \\
\hline \multirow{3}{*}{ Total coefficients } & Mean & 3.98 & 3.63 & 3,80 \\
\hline & Median & 4.0 & 3.75 & 3.75 \\
\hline & Standard deviation & 1.105 & 1.005 & 1.0662 \\
\hline
\end{tabular}

Source: Authors.

Table 2 also shows the preparation of marketing plans is the stage in which less information is shared, with a score of 3.29 , close to the center point of the scale. The low mean, 3.12, indicates the existence of a barrier between the areas due to the lack of an effective participation of the production function in this stage of the process, in which a strategic activity of the marketing area is carried out. This may be due to the long-term structural separation (Shapiro, 1977; Piercy, 2007), in which each area deliberates according to its interests, not considering the other departments in its decisions (Malhotra \& Sharma, 2002; D'Avila, 2013).

Table 3 shows that the means obtained for the four perspectives addressed in innovation performance indicated scores above the center point of the scale, with a general construct mean of 3.65. When comparing the means obtained for each area, managers agree on the indicators that have the greatest impact on innovation success. Profitability and sales were indicated by the managers as the variables of greater impact on product innovation, with means of 3.93 and 3.80 , respectively. We can observe that respondents tended to associate innovation success with financial indicators, such as profitability and sales, more frequently than with non-financial indicators, such as the development of new products cycle time and portfolio range. 
Table 3. Innovation performance.

\begin{tabular}{|c|c|c|c|c|}
\hline \multirow[b]{2}{*}{$\begin{array}{l}\text { Variables - Innovation } \\
\text { Performance }\end{array}$} & & \multicolumn{3}{|c|}{ Respondent functional area } \\
\hline & & $\begin{array}{c}\text { Marketing } \\
\text { and Sales } \\
n=41\end{array}$ & $\begin{array}{l}\text { Production } \\
\text { and } \\
\text { Operations } \\
n=41\end{array}$ & $\begin{array}{l}\text { Total } \\
\mathrm{n}=82\end{array}$ \\
\hline \multirow{3}{*}{$\begin{array}{l}\text { From a profitability point } \\
\text { of view, our new product } \\
\text { development program } \\
\text { has been successful. }\end{array}$} & Mean & 3.90 & 3.95 & 3.93 \\
\hline & Median & 4.0 & 4.0 & 4.0 \\
\hline & Standard deviation & 0.889 & 0.740 & 0.813 \\
\hline \multirow{3}{*}{$\begin{array}{l}\text { Compared to major } \\
\text { competitors, our new } \\
\text { product development } \\
\text { program has been more } \\
\text { successful in sales. }\end{array}$} & Mean & 3.90 & 3.71 & 3.80 \\
\hline & Median & 4.0 & 4.0 & 4.0 \\
\hline & Standard deviation & 0.917 & 0.750 & 0.838 \\
\hline \multirow{3}{*}{$\begin{array}{l}\text { Compared to major } \\
\text { competitors, our new } \\
\text { products development } \\
\text { cycle time has been } \\
\text { shorter. }\end{array}$} & Mean & 3.32 & 3.34 & 3.33 \\
\hline & Median & 3.0 & 3.0 & 3.00 \\
\hline & Standard deviation & 1.035 & 0.990 & 1.007 \\
\hline \multirow{3}{*}{$\begin{array}{l}\text { Our product portfolio is } \\
\text { more diverse than that } \\
\text { of our competitors. }\end{array}$} & Mean & 3.61 & 3.51 & 3.56 \\
\hline & Median & 4.0 & 4.0 & 4.0 \\
\hline & Standard deviation & 1.202 & 1.028 & 1.112 \\
\hline \multirow{3}{*}{ Total coefficients } & Average & 3.70 & 3.63 & 3.65 \\
\hline & Median & 3.75 & 3.75 & 3.75 \\
\hline & Standard deviation & 1.011 & 0.879 & 0.942 \\
\hline
\end{tabular}

Source: Authors.

The most divergent opinions among managers were related to sales success, with scores of 3.90 and 3.71. The highest standard deviation per area was also observed in this construct, with a variation of 0.917 in the marketing and commercial areas and 0.750 in the operations and production areas. This slight difference of opinions, when compared to the other variables of the construct, may be due to the predominance of respondents of the commercial area.

With an operational bias and a short-term outlook, managers could have a natural inclination to improve the results of their department, concentrating efforts to increase sales. This departmental approach is highlighted in the literature as one of the primary causes of conflicts among functions (Malhotra \& Sharma, 2002; Piercy, 2007).

Considering the integration of marketing and operations as an independent variable and innovation performance as a dependent variable, Table 4 shows regression analysis, in which we used the means obtained for each of the constructs to test the first hypothesis. 
Table 4. Regression analysis.

\begin{tabular}{|c|c|c|c|c|c|}
\hline $\mathbf{R}$ & R squared & & $\begin{array}{l}\text { Adjusted R } \\
\text { squared }\end{array}$ & & $\begin{array}{c}\text { Default } \\
\text { estimation error }\end{array}$ \\
\hline \multirow[t]{2}{*}{0.313} & 0.098 & & 0.087 & & 0.65513 \\
\hline & $\begin{array}{l}\text { Sum of } \\
\text { squares }\end{array}$ & Df & Mean squares & $\mathbf{F}$ & Sig \\
\hline Regression & 3.742 & 1 & 3.742 & 8.718 & 0.004 \\
\hline Residual & 34.336 & 80 & 0.429 & & \\
\hline \multirow[t]{3}{*}{ Total } & 38.077 & 81 & & & \\
\hline & \multicolumn{2}{|c|}{$\begin{array}{l}\text { Non-standardized } \\
\text { coefficients }\end{array}$} & $\begin{array}{c}\text { Beta } \\
\text { Standardized }\end{array}$ & $\mathbf{t}$ & Sig \\
\hline & B & $\begin{array}{l}\text { Defaul } \\
\text { t error }\end{array}$ & coefficients & B & Default error \\
\hline Constant & 2.705 & 0.340 & \multirow[b]{2}{*}{0.313} & 7.943 & 0.000 \\
\hline $\begin{array}{c}\text { Mean of } \\
\text { integration }\end{array}$ & 0.26 & 0.087 & & 2.953 & 0.004 \\
\hline
\end{tabular}

Source: Authors.

We can observe in Table 4 that the dependent variables had a positive and moderate relationship (Cohen, 1988) of $31.3 \%(R=0.313$ ) with the independent variable, the model explained $8.7 \%$ of the variation in innovation performance (Adjusted R Squared $=0.087$ ) and it was statistically significant (Sig $=0.004$ ) at the 95\% confidence level. This result supports the first hypothesis, indicating that the integration of marketing and operations has a positive and significant impact on innovation performance.

Hypotheses 2, 3, 4 and 5 were assessed by correlation analysis between the means of each variable of the first construct, integration of marketing and operations, and the total mean obtained for the innovation performance construct. The results of correlations and significance are shown in Table 5.

Table 5. Correlations between the construct variables.

\begin{tabular}{cccc}
\hline \multirow{2}{*}{ Sequence } & Stages of new product development & \multicolumn{2}{c}{$\begin{array}{c}\text { Overall mean of the construct } \\
\text { Innovation performance }\end{array}$} \\
\cline { 3 - 4 } & & Correlation & Significance \\
\hline 1 & Analysis of market opportunities & $0.366^{*}$ & 0.002 \\
\hline 2 & Marketing and Sales Testing & 0.207 & 0.062 \\
\hline 3 & Preparation of marketing plans & 0.174 & 0.119 \\
\hline 4 & Launch of new products on the market & $0.299 *$ & 0.014 \\
\hline
\end{tabular}

*The correlation is significant at the 0.01 level; ${ }^{* *}$ The correlation is significant at the 0.05 level. Source: Authors.

The positive and significant correlations found for the first and last stages of the development of new products support the hypotheses 2, 3, 4 and 5, which indicates that the sharing of information between marketing and operations in the analysis of market opportunities and the launch of new products positively impact innovation. Hypotheses 3 and 4 were not supported as they did not have significant statistical correlations, which indicates that testing products before the launch of the product 
and preparation of marketing plans, the second and third stages of the development of new products, respectively, do not have a positive effect on innovation.

Considering these results, we infer that fostering the integration of marketing and production only at the beginning and the final stages of the process might hinder the achievement of product manufacturing efficiency (Kong et al., 2015). Thus, we support the integration of efforts between the functions in all the stages of the development, so that the quality and the design of the product may be enhanced, resulting in innovation success.

After verifying and testing the hypothesis, a regression analysis was performed in each functional area of the respondents in order to verify the results. As shown in Table 6 , the results indicate that the managers of the marketing and commercial areas do not perceive the impact of the functions on innovation performance, which was confirmed by the absence of statistical significance $(\mathrm{Sig}=0.463)$ and by the weak correlation found $(R=0.118)$.

Table 6. Regression analysis divided by area.

\begin{tabular}{|c|c|c|c|c|c|c|}
\hline $\begin{array}{l}\text { Responden } \\
t \text { functional } \\
\text { area }\end{array}$ & $\mathbf{R}$ & & $\begin{array}{c}\mathbf{R} \\
\text { squared }\end{array}$ & $\begin{array}{l}\text { Adjusted } \\
\mathrm{R} \text { squared }\end{array}$ & & $\begin{array}{c}\text { Default } \\
\text { estimation } \\
\text { error }\end{array}$ \\
\hline $\begin{array}{l}\text { Marketing } \\
\text { and Sales }\end{array}$ & 0.118 & & 0.014 & -0.011 & & 0.77971 \\
\hline \multirow[t]{2}{*}{$\begin{array}{l}\text { Production } \\
\text { and } \\
\text { Operations }\end{array}$} & 0.585 & & 0.342 & 0.326 & & 0.48587 \\
\hline & & $\begin{array}{l}\text { Sum of } \\
\text { squares }\end{array}$ & Df & $\begin{array}{c}\text { Mean } \\
\text { squares }\end{array}$ & $\mathbf{F}$ & Sig \\
\hline \multirow{3}{*}{$\begin{array}{l}\text { Marketing } \\
\text { and Sales }\end{array}$} & Regression & 0.333 & 1 & 0.333 & 0.548 & 0.463 \\
\hline & Residual & 23.710 & 39 & 0.608 & & \\
\hline & Total & 24.043 & 40 & & & \\
\hline \multirow{3}{*}{$\begin{array}{l}\text { Production } \\
\text { and } \\
\text { Operations }\end{array}$} & Regression & 4.793 & 1 & 4.793 & 20.304 & 0.000 \\
\hline & Residual & 9.207 & 39 & 0.236 & & \\
\hline & Total & 14.000 & 40 & 0.333 & & \\
\hline
\end{tabular}

Source: Authors.

On the other hand, the managers of the production and operations areas perceived the integration of the functions to innovation performance as relevant. A correlation of $58.5 \%(R=0.585)$ and a high significance $(\mathrm{Sig}=0.000)$ was found. From the findings, we can propose the possible causes of this divergence.

As stated by Piercy (2007), the different experiences and knowledge of marketing and operations personnel lead to very different views of organizational priorities and goals. Thus, analyzing the results in the light of the theory, we infer that there is no consensus between marketing and commercial managers on the real benefits of cross-functional collaboration to achieve organizational priorities, which can be evaluated under important measures such as profitability and sales success. 


\section{Conclusion}

The methodology used allowed to reach the objective proposed by this study while contributing to the validation of the construct by Song et al. (2010). The scales of the proposed model were suitable for verifying and testing the hypotheses, with acceptable internal reliability (Hair et al., 2005). In Chart 2, we present a synthesis of the tested hypotheses and their respective results.

Chart 2. Synthesis of hypothesis tested.

\begin{tabular}{|c|c|}
\hline Hypothesis & Result \\
\hline $\begin{array}{c}1 \text { - There is a positive relationship between marketing and operations } \\
\text { integration and product innovation success. }\end{array}$ & Validated \\
\hline $\begin{array}{l}2 \text { - Information-sharing between marketing and operations in the analysis of } \\
\text { market opportunities has a positive effect on innovation. }\end{array}$ & Validated \\
\hline $\begin{array}{l}3 \text { - Information-sharing between marketing and operations in marketing and } \\
\text { sales testing before the launch of the product has a positive effect on } \\
\text { innovation. }\end{array}$ & Rejected \\
\hline $\begin{array}{l}4 \text { - Information-sharing between marketing and operations in the preparation } \\
\text { of marketing plans has a positive effect on innovation. }\end{array}$ & Rejected \\
\hline $\begin{array}{c}5 \text { - Information-sharing between marketing and operations in the launch of } \\
\text { new products on the market has a positive effect on innovation. }\end{array}$ & Validated \\
\hline
\end{tabular}

Source: Authors.

The validation of the first hypothesis of the study confirms the importance of the coexistence of marketing and operations, in an environment of cooperation and harmony, to achieve superior performance in the process of product innovation. The results for Brazilian managers studied in the flexible plastic packaging industry are in accordance with empirical studies developed in the United States (O'LearyKelly \& Flores, 2002; Song et al., 2010), Japan (Song et al., 2010) and China (Kong et al., 2015), confirming the positive effect of integration of the functions on innovation success.

The analysis of hypotheses 2, 3, 4 and 5 indicates that the integration of the areas in the initial and final stages of the process of development of new products areas influences innovation performance positively. This result is contrary to the finding of Swink \& Song (2007) that integration positively influence innovation success in all four stages of the process, and of Kong et al. (2015) that found this positive effect in the initial and intermediate stages of the development of new products.

The functional perspective adopted allowed the identification of different perceptions of the managers of the marketing and operations areas, confirming the conflicts between these areas already highlighted by the literature. The analysis confirmed a long-term structural separation of the departments (Piercy, 2007), which causes lack of cooperation and consulting between the areas while formulating the strategies of each function (Tang, 2010), and an excessive focus on departmental objectives to the detriment of organizational objectives (Malhotra \& Sharma, 2002).

While the analysis indicates a myopic view of managers from operational and non-strategic positions in the commercial and marketing area on the real contribution of the coexistence of the functions to innovation success, the opposite was found for the managers from the operational and production areas. The predominance of respondents occupying commercial positions indicated a strong orientation to short-term results, such as sales, which is contrary to the mission of 
strategic marketing to spread a market-oriented culture throughout the organization. Aaker (2012) argues that in a complex and dynamic market, the most successful strategy is to adopt a customer-centric orientation, in which current and latent motivations, as well as unmet needs of clients, should influence all organizational functions seeking long-term goals.

This study contributes to companies of the flexible plastic packaging industry by providing an important diagnosis of the level of integration of functions and different perceptions on the impact on innovation performance using financial and non-financial indicators. The finding could aid in making policies and processes that promote strategic alignment between marketing and operations, considering that to survive in the market, a company of this industry needs greater innovation capability and a process of product development more agile than its competitors.

The limitations of this study relate to the use of convenience sample in only a specific type of industry and the predominance of managers occupying commercial positions in the marketing area. Therefore, since the data were collected in a single industrial sector, the results found here cannot be generalized to other organizations and industries. However, it contributes to broadening the theoretical and empirical discussion about this subject.

For further studies, we suggest the replication of the methodology used in other industries, considering the divergent perspectives of the marketing and operations managers, as found in this study. Further research could investigate the different perceptions of the members of each function, thus widening the cross-cultural perspective of the topic (Tang et al., 2015). They could explore the antecedents of decisions in each area, identifying how the different backgrounds, experiences, and knowledge of marketing and operations managers (Piercy, 2007) influence the level of integration between functions in developing new products. Similarly, we suggest the investigation of how different social and cultural values of the managers of each area impact the formulation of strategies and the effect of these nuances on the achievement of organizational goals.

Further studies could also verify the efficiency of the construct and methodology used in this study in the service sector, since in services, different from goods, the performance of services occur simultaneously with the consumer interaction. Other different characteristics include its intangibility and perishability, which makes it difficult to measure. Thus, innovation in services must be perceived as a continuous process because its offering is more complex (D'Avila, 2013; Fernandes et al., 2017; Fitzsimmons \& Fitzsimmons, 2014; Motta \& Moraes, 2017; Orsini \& Karagozoglu, 1988; Tomaszewski et al., 2016).

Although this study provided a diagnosis of the level of integration of marketing and operations, indicating some points of conflict between the areas, it does not offer recommendations on how managers could increase engagement between the functions. Further studies could focus on the antecedents of integration (Kong et al., 2015), emphasizing influencing factors such as coordination mechanisms and incentive policies that may lead to an increased involvement between the areas and consequently to better innovation performance.

\section{References}

Aaker, D. A. (2012). Administração estratégica de mercado. Porto Alegre: Bookman. 
Associação Brasileira da Indústria de Embalagens Plásticas Flexíveis - ABIEF. (2017). Indústria brasileira de embalagens plásticas flexíveis tem desempenho positivo no primeiro semestre de 2017. Retrieved in 2017, November 22, from https://blogdoplastico.wordpress.com/2017/09/12/industria-brasileira-de-embalagensplasticas-flexiveis-tem-desempenho-positivo-no-primeiro-semestre-de-2017/

Associação Brasileira de Embalagem - ABRE. (2016). Estudo Macroeconômico da Embalagem ABRE/ FGV. Retrieved in 2017, November 22, from http://www.abre.org.br/setor/dados-demercado/dados-de-mercado-2016/

Baker, W. E. L., \& Sinkula, J. M. (1999). The synergistic effect of market orientation and learning orientation on organizational performance. Journal of the Academy of Marketing Science, 27(4), 411-427. http://dx.doi.org/10.1177/0092070399274002.

Basnet, C. (2013). The measurement of internal supply chain integration. Management Research Review, 36(2), 153-172. http://dx.doi.org/10.1108/01409171311292252.

Calantone, R., \& Rubera, G. (2012). When should RD \& E and marketing collaborate? The moderating role of exploration-exploitation and environment uncertainty. Journal of Product Innovation Management, 29(1), 144-157. http://dx.doi.org/10.1111/j.15405885.2011.00884.x.

Calantone, R., Dröge, C., \& Vickery, S. (2002). Investigating the manufacturing-marketing interface in new product development: does context affect relationships? Journal of Operations Management, 20(2), 73-87. http://dx.doi.org/10.1016/S0272-6963(02)00009-8.

Camilo, A. N. (2016). Inovações em embalagens flexíveis. Revista Embalagem e Tecnologia, 20-23. Retrieved in 2017, November 22, from http://embalagemetecnologia.com.br/edicoes/et26.pdf

Campomar, M. C., \& Ikeda, A. A. (2006). Falácias em marketing no Brasil. In Anais do II Encontro de Marketing da ANPAD (pp. 1-8). Rio de Janeiro: EMA.

Cohen, J. (1988). Statistical Power analysis for the behavioral sciences. Hillsdale: Erbaum.

Crawford, C. M., \& Di Benedetto, A. (2008). The products management. New York: McGrawHill.

D'Avila, L. C. (2013). Interdependência e integração entre marketing e operações nas operações de serviços (Tese de doutorado). Universidade do Vale do Rio dos Sinos, São Leopoldo.

Day, G. (1997). Aligning the Organization to the Market. In D. R. Lehman \& K. E. Jocz (Eds.), Reflections on the Futures of Marketing (pp. 67-95). Cambridge, MA: Marketing Science Institute.

Fallah, M. H., \& Lechler, T. H. (2008). Global innovation performance: strategic challenges for multinational corporations. Journal of Engineering and Technology Management, 25(1-2), 58-74. http://dx.doi.org/10.1016/j.jengtecman.2008.01.008.

Fernandes, A., D’Avila, A., Possamai, L., \& Olea, P. (2017). Identificação das inovações: estudo de caso em unidades hospitalares. Rahis, 22-35.

Fitzsimmons, J. A., \& Fitzsimmons, M. J. (2014). Administração de serviços: operações, estratégia e tecnologia da informação. Porto Alegre: AMGH Editora.

Frishammar, J., Lichtenthaler, U., \& Rundquist, J. (2012). Identifying technology commercialization opportunities: the importance of integrating product development knowledge. Journal of Product Innovation Management, 29(4), 573-589. http://dx.doi.org/10.1111/j.1540-5885.2012.00926.x.

Hair, J. F., Jr., Babin, B., Money, A. H., \& Samuel, P. (2005). Fundamentos de métodos de pesquisa em administração. Porto Alegre: Bookman.

Hausman, W., Montgomery, D., \& Roth, A. (2002). Why should marketing and manufacturing work together? Journal of Operations Management, 20(3), 241-257.

http://dx.doi.org/10.1016/s0272-6963(02)00010-4. 
Henard, D., \& Szymanski, D. (2001). Why some new products are more successful than others. JMR, Journal of Marketing Research, 38(3), 362-375.

http://dx.doi.org/10.1509/jmkr.38.3.362.18861.

Hill, T. (2005). Operations management. London: Palgrave Macmillan.

Homburg, C., Alavi, S., Rajab, T., \& Wieseke, J. (2017). The contingent roles of R\&D-sales versus R\&D-marketing cooperation in new-product development of business-to-business firms. International Journal of Research in Marketing, 34(1), 212-230. http://dx.doi.org/10.1016/j.jijesmar.2016.05.008.

Instituto Brasileiro de Geografia e Estatística - IBGE. (2017). Produto Interno Bruto valores correntes. Retrieved in 2017, December 12, from https://seriesestatisticas.ibge.gov.br/series.aspx?t=produto-interno-bruto\&vcodigo=SCN52

Jaworski, B. J., \& Kohli, A. K. (1993). Market orientation: antecedents and consequences. Journal of Marketing, 57(3), 53-70. http://dx.doi.org/10.1177/002224299305700304.

Kahn, K., \& Mentzer, J. (1994). Norms that distinguish between marketing and manufacturing. Journal of Business Research, 30(2), 111-118.

Kahn, K., \& Mentzer, J. (1998). Marketing's integration with other departments. Journal of Business Research, 42(1), 53-62. http://dx.doi.org/10.1016/S0148-2963(97)00068-4.

Keskin, H. (2006). Market orientation, learning orientation, and innovation capabilities in SMEs an extended model. European Journal of Innovation Management, 9(4), 396-417. http://dx.doi.org/10.1108/14601060610707849.

Kong, T., Li, G., Feng, T., \& Sun, L. (2015). Effects of marketing-manufacturing integration across stages of new product development on performance. International Journal of Production Research, 53(8), 2269-2284. http://dx.doi.org/10.1080/00207543.2014.932934.

Kotler, P., Rackham, N., \& Krishnaswamy, S. (2006). Ending the war between sales and marketing. Harvard Business Review, 84(7-8), 1-14. PMid:16846190.

Kwortnik, R., \& Thompson, G. (2009). Unifying service marketing and operations with service experience management. Journal of Service Research, 11(4), 389-406. http://dx.doi.org/10.1177/1094670509333595.

Lin, Y., Wang, Y., \& Kung, L. (2015). Influences of cross-functional collaboration and knowledge creation on technology commercialization: evidence from high-tech industries. Industrial Marketing Management, 49, 128-138. http://dx.doi.org/10.1016/j.indmarman.2015.04.002.

Ma, Z., Yu, M., Gao, C., Zhou, J., \& Yang, Z. (2015). Institutional constraints of product innovation in China: evidence from international joint ventures. Journal of Business Research, 68(5), 949-956. http://dx.doi.org/10.1016/j.jbusres.2014.09.022.

Malhotra, N. (2004). Pesquisa de marketing: uma orientação aplicada. Porto Alegre: Bookman.

Malhotra, N., \& Sharma, S. (2002). Spanning the continuum between marketing and operations. Journal of Operations Management, 20(3), 209-219. http://dx.doi.org/10.1016/S02726963(02)00019-0.

Mollenkopf, D., Frankel, R., \& Russo, I. (2011). Creating value through returns management: exploring the marketing-operations interface. Journal of Operations Management, 29(5), 391-403. http://dx.doi.org/10.1016/j.jom.2010.11.004.

Motta, E. M., \& Moraes, M. C. B. (2017). Proposta de atributos de serviços e de indicadores de desempenho para academias fitness. Leisure and Tourism Review, 6(1), 124-145. http://dx.doi.org/10.5585/podium.v6i1.167.

Narver, J., \& Slater, S. (1990). The effect of a market orientation on business profitability. Journal of Marketing, 54(4), 20-35. http://dx.doi.org/10.1177/002224299005400403.

O'Leary-Kelly, S. W., \& Flores, B. E. (2002). The integration of manufacturing and marketing/sales decisions: impact of organizational performance. Journal of Operations Management, 20(3), 221-240. http://dx.doi.org/10.1016/S0272-6963(02)00005-0. 
Olson, E. M., Walker, O. C., Jr., Ruekert, R. W., \& Bonner, J. M. (2001). Patterns of cooperation during new product development among marketing, operations, and R\&D: implications for project performance. Journal of Product Innovation Management, 18(4), 258-271. http://dx.doi.org/10.1111/1540-5885.1840258.

Orsini, J. L., \& Karagozoglu, N. (1988). Marketing, production interfaces in services industries. S.A.M. Advanced Management Journal, 53(3), 34.

Paiva, E., Gavronski, I., \& D'Avila, L. (2011). The relationship between manufacturing integration and performance from an activity-oriented perspective. BAR - Brazilian Administration Review, 8(4), 376-394. http://dx.doi.org/10.1590/s180776922011000400003.

Peng, G., Mu, J., \& Di Benedetto, C. A. (2013). Learning and open source software license choice. Decision Sciences, 44(4), 619-643. http://dx.doi.org/10.1111/deci.12036.

Piercy, N. (2007). Framing the problematic relationship between the marketing and operations functions. Journal of Strategic Marketing, 15(2-3), 185-207. http://dx.doi.org/10.1080/09652540701319037.

Schneider, M., \& Engelen, A. (2015). Enemy or friend? The cultural impact of cross-functional behavior on the EO-performance link. Journal of World Business, 50(3), 439-453. http://dx.doi.org/10.1016/j.jwb.2014.06.001.

Serviço de Apoio às Micro e Pequenas Empresas - SEBRAE. (2013). Anuário do trabalho na micro e pequena empresa. Retrieved in 2017, April 27, from http://www.sebraesc.com.br/leis/default.asp?vcdtexto $=4154$

Shapiro, B. (1977). Can marketing and manufacturing coexist? Harvard Business Review, 55, 104-114.

Sivakumar, K., \& Nakata, C. (2003). Designing global new product teams - optimizing the effects of national culture on new product development. International Marketing Review, 20(4), 397-445. http://dx.doi.org/10.1108/02651330310485162.

Skinner, W. (1969). Manufacturing - missing link in corporate strategy. Harvard Business Review, 47(3), 136-145.

Song, M., Kawakami, T., \& Stringfellow, A. (2010). A cross-national comparative study of senior management policy, marketing-manufacturing involvement, and innovation performance. Journal of Product Innovation Management, 27(2), 179-200. http://dx.doi.org/10.1111/j.1540-5885.2010.00709.x.

Song, M., Podoynitsyna, L., Van Der Bij, H., \& Halman, J. I. M. (2008). Success factors in new ventures: a meta-analysis. Journal of Product Innovation Management, 25(1), 7-27. http://dx.doi.org/10.1111/j.1540-5885.2007.00280.x.

Swink, M., \& Song, X. M. (2007). Effects of marketing-manufacturing integration on new product development time and competitive advantage. Journal of Operations Management, 25(1), 2003-2017. http://dx.doi.org/10.1016/j.jom.2006.03.001.

Tang, C. (2010). A review of marketing-operations interface models: from co-existence to coordination and collaboration. International Journal of Production Economics, 125(1), 22 40. http://dx.doi.org/10.1016/j.ijpe.2010.01.014.

Tang, F., Mu, J., \& Thomas, E. (2015). Who knows what in NPD Teams: communication context, mode, and task contingencies. Journal of Product Innovation Management, 32(3), 404-423. http://dx.doi.org/10.1111/jpim.12226.

Tatikonda, M. V., \& Montoya-Weiss, M. M. (2001). Integrating operations and marketing perspectives of product innovation: the influence of organizational process factors and capabilities on development performance. Management Science, 41(1), 151-172. http://dx.doi.org/10.1287/mnsc.47.1.151.10669. 
Tomaszewski, L. A., Lacerda, D. P., \& Teixeira, R. (2016). Estratégia de operações em serviços de saúde preventiva: análise dos critérios competitivos e recomendações operacionais. Gestão \& Produção, 23(2), 381-396. http://dx.doi.org/10.1590/0104-530x0827-15.

Xie, J., Song, X. M., \& Stringfellow, A. (2003). Antecedents and consequences of goal incongruity on new product development in five countries: a marketing view. Journal of Product Innovation Management, 20(3), 233-250. http://dx.doi.org/10.1111/15405885.2003005.

Zanon, C. J. (2011). Alinhamento estratégico das operações: estudos de caso na interface com marketing (Tese de doutorado). Universidade Federal de São Carlos, São Carlos. 